Tips om medisinsk litteratur, andre bøker, filmer og elektroniske medier som bør anmeldes, sendes tidsskriftet@legeforeningen.no

\section{Herlig humor til venterommet}

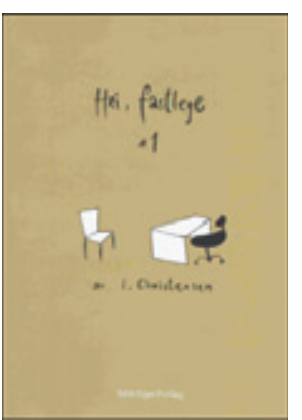

Ingunn Christensen

Hei, fastlege

152 s, ill. Oslo: MittEgetForlag, 2010.

Pris NOK 200

ISBN 978-82-997921-1-0

Hei, fastlege er en tegneseriebok som karikerer møtet mellom pasient og fastlege på en morsom, men uventet måte. Ingunn Christensen formidler og billedliggjør de små og underfundige samtalene som utspinner seg over fastlegens skrivebord - i et intimt og til tider konfliktfylt rom med ulike forventninger, roller og tolkinger. Det dreier seg om pasientens versus legens verden; den klassiske dikotomien som nå blir tatt på kornet, granskende og med en skarp blyantstrek.

Målgruppen er folk flest, men bokens minimalistiske design og retrouttrykk treffer nok best hos unge voksne og personer med akademisk legning. Med blikk for komikk og sans for ironi, fanger Christensen øyeblikk og situasjoner vi kjenner oss igjen i og som får oss til å le. Hun skaper et variert og fantasifullt persongalleri som både berører oss og ansporer til refleksjon. Her er skjemt og alvor i skjønn forening, her er kløktige observasjoner og selvopplevde hendelser.

«Hei fastlege, jeg føler at jeg ikke strekker til lenger. Hva skal jeg gjøre?» spør en åpenbart forkommen pasient. Blåveisen er ikke til å ta feil av, der han sitter hjelpeløs i stolen. Legen, en grå og forutsigbar fyr med Freud-briller dinglende på nesetippen og en dobbelthake som går i flukt med adamseplet, repliserer: «Si det, si det... Du har mange med deg. Finn ut hvor den ene enden er festa, så løsner'u på grepet. Kan gjøre vondt i prosessen, men jeg skriver ut no' Ritalin.»

Foruten en spiss blyant, benytter forfatteren enkle visuelle grep som store bokstaver og zooming for å fremheve sine poenger. Bevisst eller ubevisst spiller hun på doble budskap - et fenomen fra kommunikasjonsjournalistikken - som sammen med overraskelsesmomentet gir boken et særpreg. Likevel synes jeg at humoren iblant blir litt for sær, og dette er min eneste innvending: Når tørrvittigheten tar overhånd eller absurditetene løper løpsk, kan leseren miste retningssansen - eller få inntrykk av et middelmådig redaksjonelt håndverk.

Alt $i$ alt er dette en underholdende nisjebok du som fastlege vil trekke på smilebåndet av. Ikke minst ser jeg for meg at pasientene på venterommet ditt vil le godt og puste rolig når de blar gjennom boken, før de skal inn til legen. Nettopp derfor anbefaler jeg $H e i$, fastlege som «venteromslektyre» til landets fastlegekontorer. Boken vil garantert gjøre vel så stor suksess som all verdens moteog motorblader. Dessverre er den kun å få kjøpt via Internett-bestilling, men jeg håper mange flere oppdager den etter hvert som jungeltelegrafen går.

Tom Sundar

Skårer legesenter

Lørenskog

\section{Kort og systematisk om EKG}

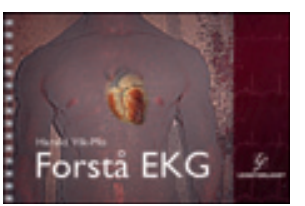

Harald Vik-Mo

Forstå EKG

110 s, ill. Trondheim: Legeforlaget, 2010.

Pris NOK 330

ISBN 978-82-92934-06-7

Dette er en systematisk, kortfattet oversikt over tyding av EKG, med kriterier for normalitet og de vanligste avvik. Funn ved hver tilstand er enkelt og didaktisk forklart. Enkle, gode illustrasjoner, og EKG av god kvalitet, følger teksten. Boken passer for studenter, som repetisjon eller systematisering for leger i spesialisering og for erfarne leger som ønsker et «skjelett» til å henge sin EKG-kunnskap på. Den er fort lest. Om man kan og husker det som står på disse få og små sidene, kan man mer enn nok EKG til vanlig bruk i allmennpraksis og sykehus. Hadde alle kursdeltakere lest denne før EKG-kursene vi holder, hadde det vært enda morsommere å undervise. Formatet passer hvis man må ha kunnskapen i frakkelommen.

En så kort bok kan ikke gi den dybdekunnskap som kreves av indremedisinere eller kardiologer. Den må suppleres med større lærebøker i infarktdiagnostikk og ikke minst arytmier, der omtalen er knapp, selv for studenter. Boken er uansett utmerket som «knaggrekke» for mer kunnskap fra andre kilder.

Jeg finner få feil og unøyaktigheter. EKG-figurene er litt underskalert, slik at man ikke kan bruke EKG-linjal på dem. Det kunne vært nevnt at store deler av verden bruker $25 \mathrm{~mm} / \mathrm{s}$, og kaller AV-blokk grad 2 av Wenckebachs type for «type I». Enkelte steder burde man ha påpekt den kortfattede fremstillingens begrensninger, og vist til at emnet er mer komplekst, f.eks. ventrikkeltakykardier. Det er etter min oppfatning innen arytmier presentasjonen kommer noe til kort. Sentrale temaer, som skillet mellom supraventrikulært og ventrikulært, er overforenklet. Atrietakykardi er utelatt. Der er litt gammeldags og ulogisk å kalle AV-nodal reentrytakykardi (AVNRT) for «paroksysmal takykardi». De fleste arytmier kan være paroksysmale. Det er ikke riktig, og farlig å tro, at pasienter med ventrikkeltakykardi som regel er sterkt sirkulatorisk påvirket. At bredkomplekstakykardi er ventrikkeltakykardi til det motsatte er bevist, burde stått med store bokstaver. Særlig på et basisnivå som denne boken sikter mot, kunne takyarytmidiagnostikken tatt utgangspunkt i, eller vært supplert med, den umiddelbare problemstilling: Smalkomplekset eller bredkomplekset, regelmessig eller uregelmessig. Man kunne med fordel utvidet arytmikapitlet med et par sider, uten å bryte det korte og summariske formatet, som er bokens styrke.

Det er uvant å se annonser/reklame i en lærebok.

Avslytningsvis er det ti «oppgaver», med fasit/forklaring, som på en utmerket måte dekker store deler av stoffet. Det kunne godt vært 20 til.

Boken kan helt klart anbefales som en basisbok for målgruppene nevnt over. Den gir mye kunnskap og systematikk på kort tid.

\section{Torkel Steen}

Hjerteavdelingen

Oslo universitetssykehus, Ullevål 